\title{
NORWID W POEZJI WSPÓŁCZESNEJ FORMY OBECNOŚCI
}

Zdaję sobie sprawę, że oprócz słowa 'Norwid', wszystkie inne, użyte w powyższej formule tytułowej, wypada wyjaśnić. Komentarza domaga się zarówno pojęcie poezji współczesnej - której kształt rodzi się na naszych oczach i wciąż jest przedmiotem negocjacji - jak i zagadnienie sposobów funkcjonowania w niej tradycji norwidowskiej. Obydwie te kategorie staram się traktować w sposób niedogmatyczny, unikając wikłania ich w niekończące się spory wokół periodyzacji dziejów literatury. Zgodnie z uniwersyteckim uzusem, w centrum moich obserwacji umieszczam teksty powstałe po 1945 roku, zachowuję jednak prawo do sięgania poza ten obszar - w głąb lat okupacji i międzywojennego dwudziestolecia. Przedmiotem podjętych przeze mnie badań nie jest też wyłącznie to, co moglibyśmy nazwać recepcją. Pojęcie obecności rozumiem o wiele szerzej - włączam weń zarówno spectrum eksplicytnych, poświadczonych tekstowo, intencjonalnych nawiązań do twórczości lub legendy Norwida, jak i obszar odniesień implicytnych, niejawnych i często przez pisarzy nieuświadomionych, wydobywanych na jaw przez historyka literatury i w tym sensie przez niego (re)konstruowanych. Dostrzegając rozległość tak wyznaczonej przestrzeni intertekstowej, stawiam sobie jednak zadanie dużo skromniejsze niż trud jej adekwatnego opisu. Wierzę, że - zanim pojawi się historycznoliteracka synteza poświęcona związkom współczesnej liryki z twórczością autora Promethidiona - warto podjąć najpierw próbę ich kategoryzacji. Że warto odpowiedzieć na pytanie o to, jaki status i kształt mają wspomniane nawiązania w twórczości poetów reprezentatywnych dla naszej współczesności. Właśnie dlatego posługuję się pojęciem form obecności. Ich opis stanowi zasadniczy cel podjętych przeze mnie rozważań. 
Obecność dzieł pisarza rozumiem zatem nie tyle jako ich statyczne trwanie w kanonie literatury, ile raczej jako ich dynamiczne uczestnictwo w procesie komunikacji, a więc - w spotkaniu. Pytanie o sposób istnienia odniesień do Norwida w poezji współczesnej jest więc dla mnie pytaniem o ich funkcję w rozmaicie wyznaczanych obszarach literackich. Choć bowiem podstawowym i niejako naturalnym terenem tego typu dociekań bywa twórczość jednego autora, to wypada przecież zauważyć, że historia literatury nie omija też obszarów działań wspólnotowych, których granice wyznaczają takie pojęcia jak grupa literacka, nurt czy generacja.

Zapytajmy więc najpierw o to, czy odczuwane niekiedy przez poetów poczucie obecności Norwida w naszej współczesności mogło pełnić funkcje integrujące, czy mogło służyć scalaniu jakiegoś realnie istniejącego środowiska literackiego? Niech będzie wolno sformułować to zagadnienie w sposób nieco bardziej prowokacyjny: czy głos dziewiętnastowiecznego mistrza dyktował dwudziestowiecznym pisarzom ich programowe wypowiedzi? Czy podpowiadał im treść poetyckich manifestów? Gdy szukamy odpowiedzi twierdzącej, naszą uwagę musi zwrócić wspólnota autorów skupionych wokół warszawskiej „Kwadrygi”. W latach 1926-1933 z pismem współpracowali przecież nie tylko Władysław Sebyła czy Konstanty Ildefons Gałczyński, ale także m.in. tak gorliwi czytelnicy Norwidowej spuścizny jak Stanisław Ryszard Dobrowolski (twórca zbioru wierszy poświęconych Norwidowi) ${ }^{1}$ i Marian Piechal (autor popularnego opracowania norwidologicznego $)^{2}$. Zdaniem Lidii Wójcik dzięki aktywności obu pisarzy projekt,,poezji uspołecznionej" - będący tożsamościowym filarem grupy - zostaje wsparty wyraźnym autorytetem Norwida ${ }^{3}$. Na łamach pisma ukazują się wypowiedzi programowe, w których postulaty dotyczące społecznej roli poety i jego moralnych powinności - zwłaszcza wobec środowisk spychanych na marines życia społecznego - inkrustowane są rozmaitymi aluzjami do myśli autora Assun$t y^{4}$. Nawiązania te, oglądane z perspektywy norwidologii dwudziestego pierwszegowieku, ukazują mocno selektywny i dość płytki sposób odczytywania norwidowskiej tradycji. Jej wielostronności i myślowego wyrafinowania nie potrafiono lub nie chciano zauważyć, zadowalając się gestami przypominającymi epigoń-

${ }^{1}$ S.R. Dobrowolski, Nad Norwidem. Poezje wybrane, Warszawa 1935.

2 M. PIECHAL, O Norwidzie (szkice), Warszawa 1937.

${ }^{3}$ L. WóJCIK, Wpływ Norwida na poezję Kwadrygi. (Fragmenty), „Przegląd Humanistyczny" 1967, nr 4, s. 59-84.

${ }^{4}$ Tamże. 
skie hołdy ${ }^{5}$. Także ranga dokonań artystycznych Dobrowolskiego i Piechala może budzić wątpliwości. Wszystko to nie zmienia jednak faktu, że właśnie w środowisku „Kwadrygi” teksty Norwida po raz pierwszy pojawiły się w roli ideowego i artystycznego spoiwa grupy literackiej i zasadniczego obszaru inspiracji dla wielu wypowiedzi poetyckich oraz metapoetyckich. Tym bardziej więc warto zapytać, czy patronat Norwida mógł się rozciągać szerzej niż granice grupy literackiej i czy poeci potrafili głębiej wejść w jego niełatwą twórczość? Odpowiedzi dostarczają łamy „Sztuki i Narodu”.

Zdaniem wielu badaczy w tekstach autorów debiutujących w mrocznych latach wojny i okupacji odniesienia do tradycji norwidowskiej są czymś więcej niż formą pamięci kulturowej ${ }^{6}$. Wydaje się, że Wacławowi Bojarskiemu, Andrzejowi Trzebińskiemu, Tadeuszowi Gajcemu i wielu innym Norwid dostarczał odpowiedzi nie tyle na pytanie o korzenie, ile raczej na pytania o poetyckie powinności. Mówił im nie tylko o przeszłości, ale także, a nawet przede wszystkim o teraźniejszości i przyszłości - o tym, kim się jest i kim powinno się być - tu i teraz, w tym, a nie innym miejscu, w tym, a nie innym momencie historii ${ }^{7}$.Odkrycia poczynione przez Przemysława Dakowicza nie pozostawiają wątpliwości co do tego, że młodzi pisarze i krytycy, skupieni wokół okupacyjnego pisma „Sztuka i Naród”, uczynili z odniesień do Norwidowej twórczości znak zrazu środowiskowej a stopniowo również generacyjnej przynależności ${ }^{8}$. Ich zwrot $\mathrm{w}$ stronę dziewiętnastowiecznego mistrza był elementem procesu ustanawiania własnej, literackiej odrębności. W roli tradycji negatywnej, ostentacyjnie (co nie oznacza, że konsekwentnie) odrzucanej obsadzano tradycję literacką międzywojnia. Ramy tradycji pozytywnej, to jest: afirmowanej, wyznaczały im dzieła Norwida. O tym, jak in-

${ }^{5}$ Współczesny badacz i poeta pisze o Kwadrygantach tak: ,ppoeci, którzy najgłośniej przyznają się do pokrewieństwa z Norwidem lub w najbardziej niewolniczy sposób naśladują jego stylistyczne wzorce, są z reguły jego najbardziej powierzchownymi epigonami”. S. BARAŃCZAK, Norwid: obecność nieobecnego, w: tegoż, Tablice z Macondo. Osiemnaście prób wyttumaczenia po co i dlaczego się pisze, Kraków 2018, s. 127.

${ }^{6}$ Por. Z. JASTRZĘBSKI, Pod znakiem Norwida, ,, Kamena” 1958, nr 16, s. 1-2; P. DAKowicz, „Lecz ty spomnisz wnuku...” Recepcja Norwida w latach 1939-1956. Rzecz o ludziach, ksiązkach i historii, Warszawa 2011.

${ }^{7}$ Dakowicz cytuje m.in. następującą opinię Zdzisława Jastrzębskiego, wyrażoną w przywołanym wyżej artykule: „młodzi poeci kształcili się na Norwidzie, by zwalczyć grozę terroru, znaleźć opanowany wyraz. [...] O to właśnie chodziło - o życiową konsekwencję poezji. Oni właściwie pierwsi zrozumieli i podjęli testament autora Vade mecum”. Por. P. DAKowICZ, s. 13.

${ }^{8}$ Periodyk wychodził od kwietnia 1942 r. do lipca 1944 r. Tuż pod winietą pisma znajdowała się parafraza formuły pojawiającej się w epilogu Promethidiona. Brzmiała jak hasło: „Artysta jest organizatorem wyobraźni narodowej”. 
tensywnie były czytane i jak wiele z nich czerpano, niech świadczy fakt, że sam imperatyw pracy nad indywidualną i zbiorową samoświadomością młodzi pisarze wywodzili z dzieł antenata, podkreślając, że wśród wojennej zawieruchy coraz trudniej człowiekowi piszącemu „"pochylić się w siebie» po norwidowsku i w wyższym bycie znaleźć punkt oparcia dla siebie i swojej sztuki”".

A przecież trzeba też przypomnieć, że sięgano do dzieł romantycznego mistrza również na wszystkich innych etapach budowania własnej literackiej tożsamości. Czytano nie tyle teksty Norwida, ile raczej samych siebie w obliczu jego dzieł. Z cytowanego opracowania Dakowicza wyłania się obraz generacji poetyckiej, która poszukuje prawdy o sobie i swych zadaniach w dziełach autora Vade-mecum. Jak pisze badacz:

W owych poszukiwaniach prawdy twórczość Norwida nierzadko pełniła funkcję drogowskazu, niekiedy stając się także trudną do sforsowania przeszkodą, budzącą „wyrzuty sumienia”, ${ }^{10}$.

Dowiadujemy się, że właśnie u autora Vade-mecum poszukiwano odpowiedzi na wcale nie akademickie pytania o to, czym jest sztuka słowa i jaka jest jej relacja do czynu. W nich próbowano odnaleźć wskazówki pozwalające określić funkcję poety w specyficznym momencie historii i ustalić społeczne znaczenie nie tylko jego pracy w mowie, ale i jego postawy moralnej. W ścisłym związku z tekstami Norwida budowano projekt życia twórczego, aktywnego, rozumianego jako kulturowa misja, obejmująca swym zasięgiem całą wspólnotę narodową. Stopniowo z łamów „Sztuki i Narodu” wyłania się ideał pisarza jako artysty zanurzonego w kulturową wspólnotę i jej aktualny moment historyczny, zobowiązanego wobec wyznawanych przez nią wartości, zaangażowanego w poszukiwanie języka zdolnego udźwignąć wspólnotowe doświadczenie i tym samym służącego prawdzie. Ta porywająca wizja nie jest jednak niczym innym niż hermeneutyką dzieł Norwida, obsadzonego w roli generacyjnego mentora. O tym, że istotnie mamy do czynienia z fenomenem nie tyle środowiskowym, ile pokoleniowym, niech świadczy fakt, że dzieła autora Promethidiona pełnią podobną funkcję we wczesnej twórczości Karola Wojtyły, niezwiązanego ze „Sztuką i Narodem”, należącego jednak do tej samej poetyckiej generacji11.

${ }_{9}$ W. BojARSKI, O nowa postawę czlowieka tworzacego, cyt za: P. DAKOwICZ, s. 22.

${ }^{10}$ Dakowicz, s. 43.

11 Por. M. URBANOwsKi, ,Widma lepszych świtan’”: renesansowy psatterz Karola Wojtyły a poezja pokolenia wojennego, w: Pisarstwo Karola Wojtyły - Jana Pawła II w oczach krytyków i uczonych, red. K. Dybciak, Warszawa 2019, s. 237-264. 
Była dotąd mowa o działaniach grupowych, o środowiskach artystów, zdobywających pisarską samowiedzę dzięki pogłębionej lekturze dzieł Norwida i definiujących swe miejsce w świecie literackim i pozaliterackim w nawiązaniu do myśli autora Promethidiona. Obecność tradycji norwidowskiej w obszarze wspólnot literackich nie zawsze jednak manifestuje się w sposób tak wyraźny, wręcz spektakularny. Warto przypomnieć, że przełom w 1956 roku otwierał u nas nie tylko nowy obszar swobód literackich, ale także nowy sposób istnienia utworów Norwida, które - wznawiane, cytowane i szeroko komentowane - z wolna stawały się elementem powszechnie dostępnego kodu kulturowego, a więc swoistym powietrzem, którym się oddycha - nieomal bez udziału woli i wiedzy. Kanonizacja dzieł poety, ich nobilitacja w obszarze kultury w istotny sposób zmieniała też sposób ich funkcjonowania w obszarze dyskursu historycznoliterackiego i krytycznoliterackiego. Podniesione do rangi kulturowego wzoru mogły pełnić funkcję swoistej literackiej miary, służącej wartościowaniu i porządkowaniu bieżącej produkcji literackiej. I rzeczywiście taką funkcję pełniły. Stanisław Barańczak w latach 80. ubiegłego stulecia pytał nieco retorycznie:

[...] czy istotnie są w dzisiejszej poezji jakieś prądy, tendencje, czy szkoły, które uznają Norwida za swojego patrona? Inaczej mówiąc: czy dzieło Norwida [...] rzeczywiście stanowi rozpoznawalny model tradycji, do którego odwoływałaby się poezja lat ostatnich?

Otóż powiem od razu, że moim zdaniem Norwid ze zwykłą sobie przewrotnością zapisał w spadku „wnukom” czy prawnukom pewien paradoks. A paradoks jest taki: wpływ Norwida w dzisiejszej poezji okazuje się najpłytszy tam, gdzie ujawnia się najbardziej manifestacyjnie; i na odwrót, pozostawił swój ślad najgłębiej tam, gdzie współcześni poeci z pozoru nie odwołują się wcale do Norwidowskiego wzoru ${ }^{12}$.

Ważnym elementem wypowiedzi krytyka wydaje się sekwencja metafor przestrzennych, wyraźnie oddzielających to, co płytkie, od głębokiego, jawne od ukrytego. W finale swej efektownej frazy badacz na poczynione rozróżnienia nakłada nową dychotomię - mocno poszerzając semantykę wywodu. To, co jawne, okazuje się nie tylko płytkie, ale i pozorne. To, co głębokie i ukryte - jawi się naszym oczom jako prawdziwe. Przypomnijmy zatem, że chodzi o dzieła Norwida, o ich komunikacyjną aktywność na terenie literatury współczesnej. Jak ów obszar jest rozumiany, możemy się jednak tylko domyślać, bo autor artykułu daje do zrozumienia, że stara się przedstawić formy obecności tradycji norwidowskiej, których nie da się uchwycić ani na terenie nawiązań intertekstualnych, ani w obsza-

${ }^{12}$ S. BARAŃCZAK, s. 120. 
rze świadomości współczesnych pisarzy; mówi o takich odniesieniach do Norwida, które skryte są w tzw. głębokich warstwach tekstu i nie zawsze mogą liczyć na wsparcie intentio auctoris. Jak zatem określić ich status ontologiczny, skoro do ich istoty należy zarówno skrytość jak i prawdziwość? Być może myśląc o tym, zbliżamy się w stronę teorii bytów intencjonalnych, których istnienie zakorzenione jest zarówno w empirii (np. tekstowej) jak i i w świadomości tego, kto ową empirię poznaje $\mathrm{e}^{13}$. Jeśli mamy wierzyć intuicjom krytyka, to odniesienia do tradycji Norwidowskiej sytuują się czasem właśnie na przecięciu tekstu i świadomości historyka literatury. Nie są zupełnie oderwane od tekstowego podłoża, ale pozostają w nim ukryte i nierozwinięte. Ich konstytutywną cechą pozostaje potencjalność. Przypominają konstrukcyjny szkielet, który potrzebuje nie tylko wyobraźni i kompetencji historyka literatury, a także jego woli, by uzyskać pełny kształt.

Można zatem powiedzieć, że istnieją takie formy obecności Norwida w naszej współczesności, które wyrastają nie tyle z oczekiwań samej literatury, ile raczej z potrzeby krytyków i historyków literatury, pomnych na swą misję systematyzowania terytorium wyjątkowo złożonego i bogatego, a zarazem wrażliwych na funkcjonujące we wspólnotach interpretacyjnych sposoby postrzegania korpusu twórczości autora Rzeczy o wolności stowa. Główna teza cytowanego artykułu Barańczaka - dotycząca funkcjonowania odniesień do Norwidowej twórczości w nurcie polskiej poezji współczesnej, nazwanym przez harwardzkiego badacza „ironicznym moralizmem” - zdaje się być zakorzeniona właśnie w takim pragnieniu i w takiej wrażliwości. Choć w rodzimej tradycji historycznoliterackiej nigdy nie wyodrębniono podobnego nurtu, rzecz przedstawiała się odmiennie w obszarach zagranicznej recepcji dwudziestowiecznej poezji polskiej. Zmiana perspektywy percepcyjnej musiała owocować zmianą sposobu porządkowania zjawisk. To, co w kraju mogło wyglądać na nie dającą się pokonać różnicę, z perspektywy odbiorcy zagranicznego prezentowało się jako jedność w wielości. W Stanach Zjednoczonych co najmniej od lat osiemdziesiątych mówiono przecież o tzw. polskiej szkole poezji i o głębokich więzach łączących twórczość takich poetów jak Czesław Miłosz, Zbigniew Herbert, Tadeusz Różewicz, Wisława Szymborska, Julia Hartwig, Adam Zagajewski i inni. Próba nazwania owych więzów, a więc powołania do istnienia nazwy pewnego nurtu, była wyłącznie kwestią czasu. Warto przywołać w całości passus,w którym autor łączy wspomniane odwołania do tradycji norwidowskiej z odważną próbą nowych uporządkowań polskiej poezji powojennej:

${ }_{13}$ Por. W. MarciszewSKI, Problem istnienia przedmiotów intencjonalnych, „Studia Semiotyczne" 1973, nr 4, s. 189-206. 
Mam na myśli nurt wcale potężny - ten, który, w braku lepszego określenia, nazwałbym banalnie ,ironicznym moralizmem”. Chronologia rozwoju tej tendencji jest skomplikowana. Ewoluuje ona przez kolejne pokolenia literackie, poczynając od Jastruna i Miłosza, kulminując w dorobku Zbigniewa Herberta, Wisławy Szymborskiej, Julii Hartwig, Artura Międzyrzeckiego, Wiktora Woroszylskiego i innych autorów urodzonych w latach dwudziestych, a kontynuację znajdując w „Pokoleniu 68”, urodzonych przeważnie już po wojnie poetach w rodzaju Ewy Lipskiej, Ryszarda Krynickiego czy Adama Zagajewskiego. [...] ,ironiczni moraliści” reprezentują różne postawy i poetyki. Ich cechą wspólną jest jednak niewątpliwie to, co Błoński nazwał „natręctwem sprzeciwu i zastrzeżenia” - sprzeciwu i zastrzeżenia zwłaszcza wobec Historii, obserwowanej z etycznego punktu widzenia - oraz częste sięganie po ironię, używanej w charakterze broni tak zaczepnej jak odpornej. Nie ulega dla mnie wątpliwości, że pod tymi dwoma względami wymienieni poeci są spadkobiercami tradycji Norwida [...] Norwid jest ukrytym patronem twórczości tych poetów ${ }^{14}$.

Wypada najpierw zaznaczyć, że - podobnie jak każda próba porządkowania zjawisk - również ta podjęta przez Barańczaka łączy się z hierarchizacją. Tradycja norwidowska została przez niego zaangażowana w mechanizm wartościowania literatury. Wiele wskazuje na to, że krytyk wybiera to, co wydaje mu się ważne w konkretnym momencie dziejów Polski, próbującej - zwłaszcza w dziedzinie kultury - uniezależnić się od aparatu komunistycznej opresji lat 80. ubiegłego stulecia. Wydaje się, że właśnie dlatego na Barańczakowej liście ,,ironicznych moralistów" brak Tadeusza Różewicza, który akurat w latach 80. intensywnie czytał Norwida ${ }^{15}$... Choć twórczość autora Płaskorzeźby pod wieloma względami mogła się wydawać dla wymienionego nurtu emblematyczna, to jednak w czasie stanu wojennego wyraźnie powstrzymywał się on od pisarskich gestów sprzeciwu wobec totalitarnego zła...

Trzeba też od razu zauważyć, że harwardzki wykładowca odwołuje się do tradycji norwidowskiej nie wprost. Bezpośrednim źródłem inspiracji nie jest dla niego twórczość dziewiętnastowiecznego pisarza, lecz jej interpretacja, dokonana przez Jana Błońskiego w głośnym artykule Norwid wśród prawnuków (ogłoszonym na łamach „Twórczości” pod koniec lat 60 . ubiegłego stulecia ${ }^{16}$ ). Tytuł tekstu sugerował, że krytyk mierzył się z niełatwym zadaniem opisania modelu czytania dzieł poety przez pewną wspólnotę interpretacyjną. W tle wypowiedzi krakowskiego badacza możemy dostrzec elementy etosu polskiej inteligencji, zawierającego w sobie - od czasów Norwida! - imperatyw sprzeciwu wobec nowoczesnych form ograniczania wolności ludzkich sumień, pasję demaskowania wszel-

${ }^{14}$ S. BARAŃCZAK, s. 136.

15 Por. K. Lisowski, Z Tadeuszem Różewiczem nie tylko o Norwidzie, „Odra” 2000, nr 4/5, s. 7-16.

16 J. BŁoŃSKI, Norwid wśród prawnuków, „Twórczość” 1967, z. 5, s. 67-94. 
kich prób zakłamywania świata wartości oraz ironiczny dystans wobec zła obecnego w historii. Barańczak konkretyzuje obraz tej osobliwej wspólnoty czytelników. Zamiast panoramy społecznej maluje portret zbiorowy, w którym rozpoznajemy twarze konkretnych pisarzy. Pytanie Jana Błońskiego o to, na ile to właśnie Norwid patronuje pod koniec dwudziestego wieku etosowi polskiego inteligenta, zamienia na pytanie o patronat autora Vade-mecum nad etosem polskiej powojennej poezji. Inaczej rzecz ujmując, czyni tradycję norwidowską elementem procesu identyfikacji i nobilitacji tej części współczesnej liryki, która zdołała oprzeć się zarówno pokusie estetyzmu, jak i skrajnej ideologizacji.

Bo też właśnie wyodrębnienie i osadzenie w zbiorowej świadomości etycznych inklinacji naszej współczesnej liryki wydaje się zasadniczym celem działań harwardzkiego polonisty, który niemal równolegle z cytowanym artykułem ogłasza Antologię poezji świadectwa i sprzeciwu 1944-1984. Poeta pamięta ${ }^{17}$. Zabiegi historyka literatury zdradzają nie tylko potrzebę uniwersalizacji poczynionych rozpoznań, ale także ich wyraźne uwikłanie w kontekst epoki stanu wojennego. We wstępie do wymienionej antologii czytamy m.in.:

Myślę po prostu, że dając świadectwo naszym czasom i wyrażając sprzeciw wobec ich niesprawiedliwości czy obłędu, poezja nie przyjmuje bynajmniej cudzych funkcji za swoje, ale spełnia właśnie te, do których ona najbardziej - z racji swojej jednostkowej, konkretnej i antysloganowej natury - jest powołana. Ktokolwiek marzy dziś o powrocie do „poezji czystej”, zapomina nie tylko o tym, że rzeczą nie całkiem czystą jest pisać „poezję czystą” w brudnych czasach, ale i o tym, że tak naprawdę poezja czysta nigdy nie istniała. Nie pisał jej w każdym razie ani Dante, ani John Donne, ani Goethe, ani Norwid ${ }^{18}$.

Także w cytowanym wyżej fragmencie rozpoznajemy charakterystyczną dla Barańczaka troskę o etyczne odniesienia literatury. Tym razem jednak krąg tradycji rozszerza się i ogarnia nie tylko twórczość Norwida, ale i kanoniczne dzieła literatury europejskiej. Krytyk powierza tradycji norwidowskiej zarówno rolę układu odniesienia dla etycznej pasji współczesnych poetów, jak i funkcję osadzania ich dokonań w kontekście literackiego kanonu zachodniego świata, od którego wbrew naszej woli odcięła nas żelazna kurtyna. Choć Barańczak nie dostarcza wystarczająco obszernych analiz materiału literackiego, by uczynić podobną hipotezę niewątpliwą, to jednak trudno odmówić jego sugestywnym wywodom inspirującej mocy i żarliwości. Niedostatki omawianego tekstu w dużej mierze uzupełnił zresztą niebawem Arent van Nieukerken w swej rozprawie Ironiczny kon-

17 Antologia poezji świadectwa i sprzeciwu 1944-1984. Poeta pamięta, wybór S. Barańczak, London 1984.

18 Tamże, s. 9. 
ceptyzm. Nowoczesna polska poezja metafizyczna w kontekście anglosaskiego modernizmu ${ }^{19}$. Jak zauważa jej recenzentka:

van Nieukerken rozwija rozpoznanie Barańczaka i wskazuje drugie źródło inspiracji powojennej poezji polskiej: anglosaski modernizm, którego polska recepcja nastąpiła głównie za sprawą lektury wierszy Thomasa Stearnsa Eliota i Wystana Hugha Audena ${ }^{20}$.

Zarówno w tym, jak i w swych kolejnym opracowaniu niderlandzki badacz dostarcza obszernej argumentacji na rzecz tezy o europejskości Norwida i o roli tradycji norwidowskiej w integrowaniu polskiej liryki z literackim kanonem Zachodu $^{21}$.

Mimo wszystko w omawianym wyżej artykule Stanisława Barańczaka wcale nie tak łatwo odróżnić to, co intersubiektywne, od tego, co najgłębiej osobiste i oddzielić to, co bywa opisem dialogu współczesnej liryki z tradycją norwidowską od tego, co j e st owym dialogiem. Autor tekstu to przecież nie tylko historyk i krytyk literatury, ale także ważny przedstawiciel przedstawianego przez siebie nurtu. Jego konstatacje, dotyczące Norwidowego patronatu nad ,ironicznymi moralistami”, są częścią narracji o charakterze tożsamościowym, mają walor osobistego wyznania i ciężar manifestu poetyckiej samoświadomości. Lektura programowych wypowiedzi Barańczaka - m.in. z tomu Etyka i poetyka - nie pozostawia wątpliwości co do tego, że współbrzmią one z metapoetycką myślą Norwida. Jeśli w dziele dziewiętnastowiecznego mistrza współczesny autor dostrzega imperatyw krytycyzmu, ironicznego dystansu i pasji demaskatorskiej wobec wszelkich form zakłamywania rzeczywistości lub deprecjacji fundamentalnych wartości, to warto przypomnieć choćby niektóre tezy o powinnościach poezji, zawarte w jego słynnym manifeście z 1970 roku:

19 A. van NiEUKERKEN, Ironiczny konceptyzm. Nowoczesna polska poezja metafizyczna w kontekście anglosaskiego modernizmu, Kraków 1998.

20 A. KlubA, A. van NieUKERKEN, Ironiczny konceptyzm. Nowoczesna polska poezja metafizyczna w kontekście anglosaskiego modernizmu, „Pamiętnik Literacki” 2001, z. 1, s. 246.

${ }^{21}$ A. van Nieukerken, s. 86-110. Por także A. van Nieukerken, Perspektywiczność sacrum - szkice o Norwidowskim romantyzmie, Warszawa 2007. 
Powinna być nieufnością. Krytycyzmem. Demaskatorstwem. Powinna być tym wszystkim aż do chwili, gdy z tej Ziemi zniknie ostatnie kłamstwo, ostatnia demagogia i ostatni akt przemocy $^{22}$.

Trudno dziś orzec, na ile współczesny poeta znał twórczość Norwida, gdy zapisywał cytowane sentencje, równie trudno byłoby jednak zaprzeczyć, iż są one istotną częścią Barańczakowego dialogu z autorem Rzeczy o wolności słowa. Toczył się on przez wiele lat i pozostawił - zwłaszcza w późnej twórczości nowofalowego poety - liczne ślady. Jeden z nich zgromadził już wokół siebie całkiem pokaźną literaturę przedmiotu - mam na myśli wiersz Garden party pozostający w wyraźnym intertekstualnym związku z Ostatnim despotyzmem Norwida ${ }^{23}$. Inne - mniej wyraźne - wciąż domagają się naszej uwagi. Niech jak zobowiązanie dla przyszłych badaczy zabrzmi deklaracja poety: „dla mnie osobiście tradycja Norwida jest zapewne najważniejsza z całej historii polskiej poezji"24.

Porzucając krąg poetyckich „organizmów zbiorowych” znaleźliśmy się zatem na terenie relacji bilateralnych. O ile bowiem w pierwszym z wymienionych obszarów obecność Norwida musi pozostawać w ścisłym związku z ramami tożsamości grupowej, o tyle w drugim chodzi o relację indywidualnego podmiotu z korpusem cudzej twórczości, traktowanym jako manifestacja konkretnego pisarskiego ,ja"25. Zdarza się jednak - zwłaszcza wtedy, gdy mówimy o implicytnych śladach obecności Norwida w poezji współczesnej - że płaszczyzna relacji pomiędzy tekstami pisarzy nie bywa przez interpretatorów przywoływana. Niekiedy dialog jako kategoria badawcza znika wtedy z pola ich obserwacji, a korpus dzieł Norwida jest traktowany przez interpretatorów jedynie kontekstowo - sta-

22 S. BARAŃCZAK, Kilka przypuszczeń na temat poezji współczesnej, w: tegoż, Etyka i poetyka. Szkice 1970-1978, Paryż 1979, s. 264.

23 Por. A. Skrendo, Stanisław Barańczak: widma poezji, „Teksty Drugie” 2014, nr 2, s. 284-306. A. van Nieukerken, Norwid Europejski, „Studia Norwidiana” 11: 1993, s. 25-26. D. Pawelec, Czytając Barańczaka, Katowice 1995, s. 129. M. TomczyK, Jak czytać wiersze?, Bielsko-Biała 2007, s. 156-168.

24 „Poezja musi być wieczna czujnością”. Rozmowa z Piotrem Wierzchosławskim, w: S. BARAŃcZAK, Zaufać nieufności, Kraków 1993, s. 71.

${ }^{25}$ Obszar indywidualnych nawiązań do poezji i legendy Norwida we współczesnej poezji jest - jak można się domyślać - trudny do ogarnięcia. Autor Vade-mecum przez wiele lat był najczęściej cytowanym u nas autorem - także na terenie poezji. Powstawały specjalne antologie zbierające współczesne wiersze zawierające odniesienia do jego twórczości. Dobrym przykładem tego typu działań jest inicjatywa krakowskiego oddziału SPP, zwieńczona antologią Z Norwidem. III Wigilia Słowa, red. J. Lubart-Krzysica, Kraków 1992. Podjęte przeze mnie obserwacje podporządkowane są idei reprezentacji. Koncentruję się jedynie na tych obszarach tekstowych, które zawierają ślady najbardziej intensywnych relacji z twórczością Norwida. 
je się pewnego rodzaju skojarzeniem, lustrem, które służy badaczowi pełniejszej prezentacji jakieś właściwości twórczości wybranego autora lub motywu, który w niej występuje. Te i podobne przypadki instrumentalnych użyć twórczości Norwida pozostają poza zasięgiem podjętych przeze mnie obserwacji. Syntetyczny charakter niniejszych rozważań skłonił mnie do skupienia się na najważniejszych formach funkcjonowania autora Quidama w naszej współczesności - tych, które osiągają wymiar spotkania (udanego lub nieudanego).

Obecność Norwida w autorskich korpusach współczesnych wierszy interesuje mnie zatem w szczególny sposób wtedy, gdy jest w nich wydarzeniem - czymś, co w jakiś sposób poszerza literacką tożsamość ich autorów i skłania ich do poszukiwania nowej, doskonalszej formy pisarskiego istnienia. Myślę najpierw o poezji Mieczysława Jastruna, bo chyba w żadnej innej ów wydarzeniowy wymiar dialogu z autorem Vade-mecum nie prezentuje się tak wyraźnie. Przypomnijmy: jeszcze w czasie drugiej wojny światowej poeta i gorliwy czytelnik Promethidiona aktywnie włącza się w prace komunistycznego aparatu władzy, odgrywa znaczącą rolę we wprowadzeniu fragmentów Norwidowej twórczości do kanonu lektur szkolnych $^{26}$. Chętnie nawiązuje też w swych wierszach do twórczości antenata, tworząc program poezji zaangażowanej „,W walkę narodu o wolność i wyzwolenie społeczne" ${ }^{27}$, a tuż po wojnie podejmuje wysiłek ,zaadaptowania dzieła autora Vade-mecum dla potrzeb socrealistycznej wizji rzeczywistości" ${ }^{28}$. Co więcej: posługuje się autorytetem Norwida „dla legitymizacji «współczesności» czyli rodzącego się ustroju komunistycznego"29. Już wkrótce jego spojrzenia na świat, a więc i na twórczość dziewiętnastowiecznego mistrza zmienia się jednak radykalnie. Celne zdanie Przemysława Dakowicza - „Swoją polemikę ze zwolennikami partyjnej kontroli nad literaturą i sztuką zaczyna Jastrun od dowołania się do... Norwida" ${ }^{30}$ - ma rangę symbolu. Zdaje się chwytać istotne uwarunkowania wewnętrznej przemiany współczesnego poety, samą istotę procesu, w którym autor Vade-mecum rzeczywiście pociąga za sobą młodego pisarza, każe mu iść za sobą i pełni funkcję przewodnika w niełatwej drodze do prawdy o rzeczywistości.

Z cytowanego opracowania Dakowicza z wolna wyłania się pasjonujący obraz autentycznej, głębokiej relacji pomiędzy obydwoma pisarzami. Filozofowie spotkania zwracają niekiedy uwagę na to, że jest ono nie tyle zagrożeniem dla tożsa-

${ }^{26}$ Por. M. Inglot, Mieczystawa Jastruna lwowskie spotkania z Norwidem (1939-1941), „Studia Norwidiana” 7: 1989, s. 119-126.

27 J. Trznadel, O poezji Mieczysława Jastruna, Warszawa 1954, s. 70.

${ }^{28}$ P. DAKowicz, s. 256.

29 Tamże, s. 249.

30 Tamże, s. 262. 
mości ,ja” ile raczej szansą na jej dopełnienie, „Ja” potrzebuje „ty”, by stać się w pełni sobą ${ }^{31}$. Dialog pomiędzy Jastrunem i Norwidem jest spotkaniem w takim właśnie sensie. Jak pokazuje norwidolog, to lektura dzieł autora Rzeczy o wolności słowa sprawia, że swój dotychczasowy sposób widzenia świata przez filtr komunistycznej ideologii młody pisarz uznaje za coraz bardziej problematyczny i coraz bardziej natarczywie poszukuje innej, nowej perspektywy oglądu rzeczywistości literackiej i pozaliterackiej. Można rzec, że w jakimś sensie dzięki Norwidowi czuje się zakwestionowany w swym dotychczasowym światoodczuciu, dzięki antenatowi odkrywa w samym sobie jakieś uwierające „nie-ja”, rozpoznaje swoją własną nieautentyczność i zniewolenie. Nie może więc nie stawiać sobie pytań o własną tożsamość i o to, co jest w niej najbardziej rudymentarne, nie może nie poszukiwać tego, co rozpoznaje jako najbardziej własne. Dakowicz - śledząc krok po kroku ślady obecności Norwida w pismach współczesnego autora; skrupulatnie analizując gęstą sieć Jastrunowych aluzji do sformułowań antenata oraz parafraz i cytatów jego wypowiedzi - przekonująco udowadnia tezę, że lektura dzieł romantycznego mistrza pomaga młodemu poecie na nowo rozpoznać w sobie imperatyw nie tyle ideologicznej, ile etycznej troski i sformułować koncepcję poezji służącej nie tyle utopii, ile prawdzie. Spotkanie z Norwidem pozwala autorowi rozliczyć się z własnym uwikłaniem w stalinizm i pomaga mu w jakiejś mierze na nowo stać się sobą. „Wiele wskazuje na to, że w początku 1955 roku Mieczysław Jastrun, podejmując po raz kolejny lekturę Norwida, odnalazł swój prawdziwy głos, przynajmniej częściowo zagłuszony i stłumiony w epoce socrealizmu - głos moralisty, surowego strażnika wartości” - konkluduje badacz ${ }^{32}$. Jak czytamy, sformułowany przez pisarza pod koniec lat 50 . i realizowany potem projekt poezji, której obowiązkiem jest przyświadczania wartościom i dawanie świadectwa prawdzie, ma swe korzenie w tradycji norwidowskiej. Wokół niej współczesny poeta oplata kolejne tomy swych wierszy w których - tak jak u Norwida - słowami-kluczami stają się 'sumienie' i 'prawda' ${ }^{33}$. Jastrunowski sarkazm okazuje się refleksem Norwidowej ironii ${ }^{34}$. Historiozofia wpisana w lirykę Jastruna - echem Norwidowego namysłu nad sensem dziejów ${ }^{35}$. Pasja tropienia współczesnych kłamstw - kontynuacją moralistyki rodem z Vade-mecum. Także jako intelektualista i jako poeta kultury „Jastrun jest spadkobiercą Norwida" ${ }^{\text {36 }}$ - pozo-

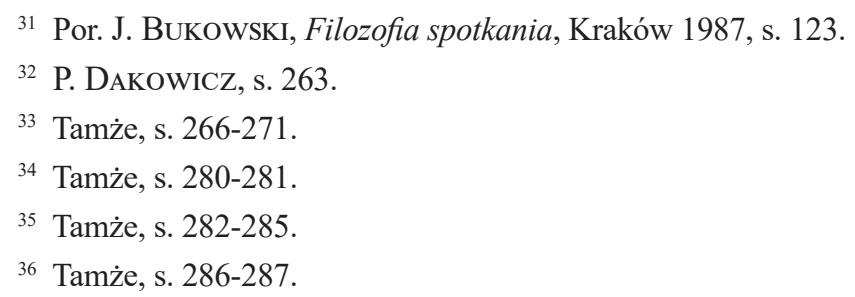


stając mimo to, a może właśnie dlatego w pełni oryginalnym polskim poetą drugiej połowy XX wieku.

Jastrunowa przygoda z autorem Quidama wydaje się zatem niemal wzorcowym przykładem relacji, w której współczesny autor nie tylko odkrywa otwartość Norwidowego dzieła wobec naszej współczesności oraz jego komunikacyjną atrakcyjność, ale także sam stara się przezwyciężyć właśnie ograniczenia i jako pisarz otwiera się na cudzy głos. Stawką jego wysiłków jest dialog, który doprowadzi go do przeformułowania własnego miejsca w literaturze i odkrycia nowej perspektywy widzenia świata oraz języka. Czy wielu pisarzy chciało wówczas - na przełomie lat 50. i 60. - grać o podobną stawkę, to oczywiście osobny problem...

Wiele dają do myślenia zwłaszcza zmagania Juliana Przybosia, którego stosunek do Norwida pełen jest trudnych do przezwyciężenia napięć i nieusuwalnych sprzeczności. Mieczysław Jastrun nie był wszak w swej fascynacji Norwidem odosobniony. W trudach związanych z umieszczeniem poety w socjalistycznym kanonie lekturowym aktywnie wspierał go właśnie lider Krakowskiej Awangardy, który z czasem stał się cenionym interpretatorem kilku wierszy autora Assunty. Właśnie jako komentator i popularyzator tekstów Norwida doczekał się niedawno osobnej monografii pióra Małgorzaty Rygielskiej ${ }^{37}$. Traktując Przybosiowe teksty norwidologiczne jako swego rodzaju lekturowe palimpsesty, autorka z wielką starannością i determinacją odsłania kolejne warstwy uwarunkowań interpretatora - jego erudycję i emocje, ale też uwikłanie w specyficzną doktrynę poetycką. Badaczka raz po raz daje do zrozumienia, że awangardowy poeta nie tyle bezinteresownie poznaje Norwidowe utwory, ile raczej stara się sprawdzić ich zgodność z wyznawaną doktryną poetycką. Że pisze on nie tyle o nich, ile wobec nich - o swojej własnej teorii poezji i własnym horyzoncie oczekiwań wobec liryki ${ }^{38}$. Patrząc na podobny model lektury przez pryzmat filozofii spotkania, moglibyśmy dojść do wniosku, że Przyboś stawia znak równości pomiędzy tym, co inne i tym, co obce - zdaje się deprecjonować i odrzucać wszystko to, co nie mieści się w ramach awangardowej doktryny - choćby były to elementy dla liryki Norwida konstytutywne $^{39}$. Przemysław Dakowicz podkreśla, że wiele spostrzeżeń interpretatora uderza jednak trafnością, co mogłoby oznaczać, że „Przybosia stać na przekroczenie własnych uprzedzeń i wniknięcie w rzeczywistość wewnętrzną poety

${ }^{37}$ M. RYGIELSKA, Przyboś czyta Norwida, Katowice 2012.

38 Zwraca na to uwagę także recenzentka książki. Por. A. KwIATKOwsKA, M. RYGIELSKA, Przyboś czyta Norwida, „Pamiętnik Literacki” 2015, z. 4, s. 233-240.

39 Pisze o tym także S. BARAŃCZAK, s. 139. 
o całkowicie odmiennym światopoglądzie i wyznawanym systemie wartości”40. W postawie awangardowego poety badacz dostrzega wahanie, jakby ten wzbraniał się przed uczestnictwem w rozmowie. Jak czytamy:

Norwid przyciąga i fascynuje jako mistrz rzemiosła poetyckiego, twórca o rzadko spotykanej samoświadomości artystycznej, odpycha i budzi zniechęcenie, gdy czyni z poezji trybunę walki o przemianę świata i człowieka, o przebudowę rzeczywistości w oparciu o moralną naukę Kościoła ${ }^{41}$.

W podobny sposób Przyboś zdaje się też organizować swe relacje z romantycznym mistrzem na terenie własnej liryki. Stosunkowo rzadko sięga do norwidowskiej tradycji, a płaszczyznę ewentualnego dialogu obu poetów zdaje się wyznaczać jedynie podobieństwo pewnych elementów języka poetyckiego i koncepcji poezji jako sztuki słowa. Nawet w tym obszarze trudno jednak mówić o spotkaniu. Jak pokazuje Dakowicz, Norwida „praca w mowie” ma zupełnie inny cel niż Przybosiowe „działania na języku” :

W twórczości Norwida [...] język nie był celem, ale środkiem docierania do istoty człowieczeństwa odniesionego do Boga i rzeczywistości nadprzyrodzonej ${ }^{42}$.

Na progu spotkania - tak chyba wypadałoby określić relację awangardowego poety i romantycznego sztuk-mistrza.

Jeśli mówimy o Przybosiowym nie-porozumieniu się z autorem Assunty lub ściślej rzecz ujmując - o trudnym dialogu obu pisarzy, to natychmiast pojawia się pytanie o to, jak mówić o takich spotkaniach, które albo nie toczyły się w tak jawnej przestrzeni jak interpretacje konkretnych wierszy, albo nie pozostawiły wyraźnych śladów w materii lirycznej współczesnego autora? Przypomina się choćby twórczość Zbigniewa Herberta, w której dostrzegamy niewiele intertekstualnych odniesień do dzieł autora Quidama ${ }^{43}$, zarazem jednak potrafimy wskazać obecne w niej elementy realnego dialogu, toczącego w obszarze troski o dostojeństwo

${ }^{40}$ P. DAKOWICZ, s. 304.

${ }^{41}$ Tamże.

42 Tamże s. 325.

${ }^{43}$ Poeta mówi o „czarnym i białym Norwidzie” w wierszu Pora. Interpretacje tego tekstu odnajdujemy w pracy M. MiKOŁAJCZAK, Światy z marzenia. Echa romantyczne w poezji Zbigniewa Herberta, Kraków 2013, s. 111-120. 
mowy ${ }^{44}$, na terenie rozumienia piękna ${ }^{45}$, kultury, historii czy też stosunku do tradycji ${ }^{46}$ i fundamentalnych wartości ${ }^{47}$. Wydaje się, że znów jesteśmy w kręgu takiej obecności Norwida w tekstowym świecie współczesnych autorów, której wypada przyznać status bytu intencjonalnego, umocowanego ontycznie nie tylko w literaturze, ale i w świadomości jej czytelników. Ten zapośredniczony charakter dialogu dwudziestowiecznych pisarzy z tradycją norwidowską w sposób szczególnie wyrazisty rysuje się na terenie twórczości autorów, którzy w sposób jawny, a często nawet deklaratywny zaprzeczali swoim związkom z Norwidem. Wyjątkowo jaskrawy wydaje się casus Czesława Miłosza, który wielokrotnie manifestował swą niechęć wobec „lechickości” autora Promethidiona oraz wobec jej propagatorów i sytuował swą twórczość raczej w pobliżu Adama Mickiewicza niż Cypriana Norwida. Gdyby nie cenna monografia Tomasza Garbola, być może do dziś wierzylibyśmy w zapewnienia poety ${ }^{48}$. Lubelski badacz postanowił jednak nie zatrzymywać się na opiniach autora Doliny Issy i zszedł do wnętrza jego dzieł, wnikliwie analizując ukryte w nich sensy. Wyniki jego badań są zaskakujące. Okazuje się, że w głębi literackiej twórczości Miłosza otwiera się przestrzeń intrygującej korespondencji jego myśli z myślą Norwida.

Według lubelskiego badacza płaszczyznę spotkania obydwu autorów tworzy wielki temat Upadku. Paralele ujawniają się już w samym sposobie jego ujęcia. Inaczej niż Mickiewicz, ale za to podobnie jak Norwid, współczesny pisarz nie koncentruje się na emocjach, ponad „racje serca” przenosi intelekt ostentacyj-

${ }^{44}$ Por. M. Adamiec, Troska o prawdziwe dostojeństwo mowy, w: Dialog i spór. Zbigniew Herbert a inni poeci i eseiści, red. J. Ruszar, Lublin 2006, s. 46-63.

${ }_{45}$ Por. M. MikolajCZaK, Czy piękno ocala? O jednym z wątków dialogu Herbert-Norwid, w: taż, Światy z marzenia. Echa romantyczne w poezji Zbigniewa Herberta, s. 93-110.

46 Tamże, s. 121-129.

47 Prócz wymienionych dotąd prac poświęconych dialogowi Herberta z Norwidem warto wskazać też artykuły zamieszczone w tomie Bór nici. Wątki klasyczne i romantyczne w twórczości Zbigniewa Herberta, red. M. Mikołajczak, Kraków 2011. (Por. np. J. ZACH, , Czas wzbogacony”. Norwid i Herbert - próba zbliżenia, s.183-195; M. AdAmieC, Na co? Po co? I dlaczego? O relacjach Norwid - Herbert kilka myśli, s. 219-231; P. ABRISZEWSKA, Literacka refleksja Cypriana Norwida i Zbigniewa Herberta nad historia tryumfalna i historia ukryta, s. 249-268; W. ToRUŃ, „Syn-minie pismo, lecz ty spomnisz, wnuku”. Herbert - Norwid, s. 269-278; tegoż, Rozmyślania o cierpieniu: Norwid - Herbert, s. 279-292; P. MichaŁOWsKI, (Prze)milczenie współczesności u Norwida i Herberta, s. 303-320. Potrzeba całościowego, monograficznego ujęcia spotkania Herberta z Norwidem wydaje się coraz bardziej paląca.

48 Przez pewien czas były one w miłoszologii mocno utrwalone. Por. A. FIUT, Spór z Lechitą, w: tegoż, W stronę Miłosza, Kraków 2003, s. 91-92. 
nie zwrócony w stronę teologii. Jej formuły - tak jak autor Do Najświętszej Panny Marii. Litanii - uznaje wprawdzie za niewystarczające, ale jednak ważne i chwytające rozmaite aspekty doświadczeń egzystencjalnych. Zdaniem Garbola Miłosz, tak jak autor Rzeczy o wolności słowa, nawet wobec skandalu zła powściąga emocje, zachowuje dystans wobec hasła „czynu narodowego”, niepoprzedzonego racjonalnym namysłem. Jego ideowe powinowactwo z Norwidem jeszcze wyraźniej rysuje się oczywiście tam, gdzie obaj pisarze zderzają się z tym, co można nazwać odwiecznymi problemami ludzkości. Monografista Miłosza przekonująco udowadnia, że mierząc się z zagadnieniem źródeł zła, autor Metafizycznej pauzy wyraźnie przeciwstawia się przecież romantycznej opozycji „,dobra Natura - zły człowiek". Tak jak Norwid dostrzega głębokie skażenie Natury i możliwość jej ostatecznej „naprawy” w wydarzeniu Wcielenia Chrystusa i Paruzji. Nie do przyjęcia jest więc dla niego zarówno wiara Mickiewicza w to, że sam człowiek jest zdolny (na drodze metempsychozy) do udoskonalenia siebie i świata, jak i Mickiewiczowe zwątpienie w możliwość zbawienia tego, co cielesne. Odpowiedzią autora Ziemi Ulro na pytanie o sens dziejów nie jest też - jak u autora Ksiag narodu polskiego i pielgrzymstwa polskiego - mesjanizm. Podobnie jak Norwida, razi go zawężenie przesłania Ewangelii do „sprawy narodowej”. Choć - zdaniem lubelskiego badacza - trudno byłoby przypisać Miłoszowi niezachwianą wiarę w sens dziejów, to jednak jego historiozofia nie jest zbytnio oddalona od Norwidowego uniwersalizmu i nadziei na „przepalenie globu - sumieniem”. Podobnie jak autor Vade-mecum, wyraźnemu w Dziadach, prometejskiemu poczuciu wyjątkowości i wyniesienia ponad „tłum” poeta XX-go stulecia przeciwstawia problem „zapomnienia” o „królewskiej” godności każdego człowieka i... postawę dziecięcego podziwu dla świata. Każdą z powyższych tez Garbol poprzedza obszerną analizą tekstową pokazując, iż mamy do czynienia z rzeczywistą osmozą idei. Choć na powierzchni, w sferze opinii Miłosz wydaje się unikać dialogu z Norwidem, to jednak w głębi swych utworów nieustannie rozmawia z dziewiętnastowiecznym antenatem...

Jeszcze inną formę ma obecność Norwida w dziele poetyckim Tadeusza Różewicza. Na pierwszy rzut oka trudno dostrzec wśród wielkich idei i tematów autora Szarej strefy obszar rozmowy z dziewiętnastowiecznym mistrzem. Nie stał się też Różewicz interpretatorem jego utworów, choć miał zamiar napisać o Norwidzie książkę ${ }^{49}$. Począwszy od tomu Płaskorzeźba poeta sukcesywnie wplata za to w swe utwory pasma gęstej sieci cytatów, kryptocytatów, parafraz fragmentów wierszy autora Vade-mecum lub aluzji do nich, zręcznie wzbogacając tkankę

49 Por. T. RóżEwicz, To, co zostało z nienapisanej książki o Norwidzie, „,Kwartalnik Artystyczny" 2002, nr 3, s. 9-25. 
znaczeniową swej liryki ${ }^{50}$. O swojej fascynacji rozmaitymi elementami twórczości autora Promethidiona wspomina też w różnego rodzaju wypowiedziach autotematycznych ${ }^{51}$. Mówi o długotrwałej i zażyłości z dziełem autora Quidama. Czy mamy zatem do czynienia z autentycznym spotkaniem emblematycznego poety ponowoczesności z romantykiem? Czy rzeczywiście chodzi Różewiczowi o dialog, czy wyłącznie o rodzaj gry literackiej? Z podobnymi pytaniami mierzyło się kilkoro badaczy, powstaje też monografia na temat relacji Różewicz-Norwid, pióra Grażyna Halkiewicz-Sojak ${ }^{52}$..

Nawiązując do istniejących już opracowań ${ }^{53}$, chciałbym obrysować choćby najgrubszą kreską kształt, jaki przybiera spotkanie z Norwidem w późnej twórczości Różewicza. Niech wolno mi będzie skupić się na chwilę na jednym liryku, który wdaje mi się dla wspomnianej relacji szczególnie charakterystyczny. Mam na myśli wiersz Taki to mistrz:

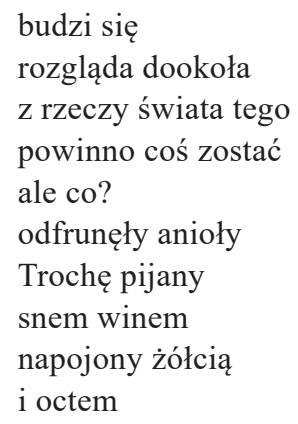

${ }^{50}$ Por. K. GuTKowsKa, Intertekst, historia i (auto)ironia: szkice o twórczości Tadeusza Różewicza, Katowice 2012, zwłaszcza rozdz. Gra Mistrzów: Różewicz i Norwid.

${ }^{51}$ Por. K. SAwickA, Norwid Tadeusza Różewicza - deklaracje, w: Polska literatura wspótczesna wobec romantyzmu, red. M. Łukaszuk, D. Seweryn. Lublin 2007, s. 129-141. A także taż, Różewicz-Norwid, w: Dialogi romantyczne, red. E. Kasperski, T. Mackiewicz. Warszawa 2008, s. 391-409.

52 Warto podkreślić, że Halkiewicz-Sojak - obserwując skalę zjawiska - zaproponowała ujęcie diachroniczne, pozwalające śledzić dynamikę relacji obu autorów. Niech mi wolno będzie w tym miejscu podziękować autorce za możliwość wglądu w pierwszą część powstającej rozprawy.

${ }^{53}$ Wśród tekstów poświęconych relacji Różewicz-Norwid G. Halkiewicz-Sojak wymienia m.in. następujące: W. RzońCA, Norwid-uwarunkowania ponowoczesności dzieła, w: Norwid z perspektywy XXI wieku, red. J. Rogoziński, Pułtusk 2003; K. SAWICKA, Stowo wobec rzeczywistości - o poezji Tadeusza Różewicza („Słupskie Prace Filologiczne” 7/2009, s. 136-159); A. JARZYNA, ,Pójście za Norwidem”, Lublin 2013 (zwłaszcza rozdz. Różewicz czyta Norwida ,od prawie 60 lat"), A. BAGLAJEWSKI, Obecność romantyzmu, Lublin 2015 (zwłaszcza rozdz. Norwidowskie ślady i obecności). 


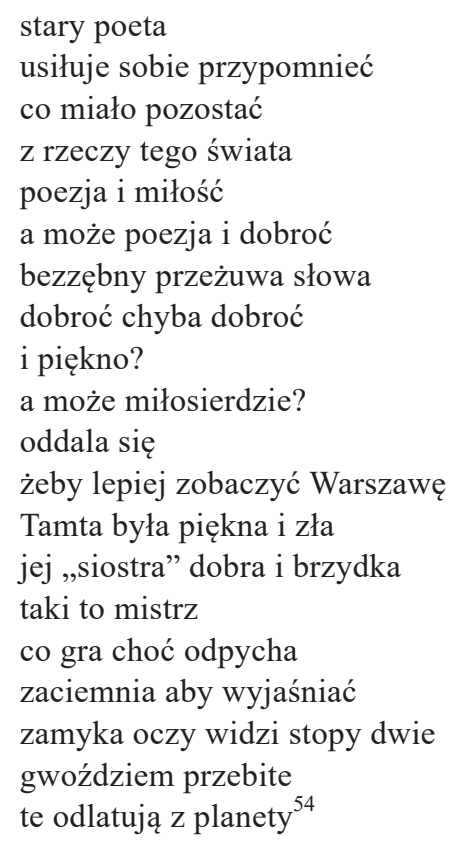

Czytelnicy Norwida nie bez satysfakcji dostrzegą w tym utworze obecność fragmentów aż trzech utworów romantycznego mistrza. Katarzyna Gutkowska przypomina, że Różewicz wykorzystuje zakończenie wiersza Do Bronisława Z:

Z rzeczy świata tego zostaną tylko dwie,

Dwie tylko: p o e z j a i d o bro ć... i więcej nic...

Że parafrazuje finał liryku Do Zeszłej:

Tam stopy dwie - gwoźdźmi przebite -

Uciekające z planety...

$* * *$

Tam - milion moich słów; tam - lecą i te.

I że nieco przekształca zdanie z Fortepianu Szopena: „Czy taki Mistrz!... że gra... choć odpycha?... "55. Poza zasięgiem badaczki pozostają jednak funkcje Różewiczowych przytoczeń, stąd kilka poniższych domysłów.

${ }^{54}$ T. Różewicz, Wyjście, Wrocław 2004, s. 18.

${ }^{55}$ K. GutKowsKa, s. 19-24. 
Wydaje się bowiem, że Różewicz dokonuje rekontekstualizacji takich fragmentów utworów autora Vade-mecum, które mają status „skrzydlatych słów” i weszły do skarbca polskiej kultury. Współczesny poeta sięga do tych szczególnych zasobów językowej pamięci polszczyzny, wybiera interesujące go zwroty i przenosi je z ich macierzystego środowiska do swojej własnej twórczości. To, co było integralną częścią tekstu Norwida, na powrót czyni zatem materią słowną, której powierza rolę elementów konstrukcyjnych w tworzonym przez siebie liryku. Ów proces poetyckich zapożyczeń, dokonywanych w czasie aktu twórczego, trudno jednak w przypadku omawianego wiersza postrzegać jako zawłaszczenie, odbierające frazom dziewiętnastowiecznego poety ich źródłowy sens. Wiele wskazuje na to, że przeniesione w ramy innego tekstu zachowują one zasadniczą część swego semantycznego profilu. Zamiana polega nie tyle na rugowaniu ich pierwotnych znaczeń, ile raczej na poszerzeniu ich zakresu o wszystko to, co wynika z umieszczenia ich w otoczeniu różewiczowskiego idiomu poetyckiego.

Obecne w cytowanym utworze toposy „odchodzącego Boga”, „zanikającego sacrum” czy też „zapoznanego mistrza" i „starego poety” - wpisane w Norwidowe archeteksty - są zarazem integralną częścią poetyckiego imaginarium Różewicza i pojawiają się w jego wielu innych utworach. Zabiegi współczesnego poety mogą więc nieco przypominać prace translatora. Współczesny pisarz tłumaczy zdania Norwida na swój własny język poetycki, dokonuje swoistego przekładu sensów Norwidowego oryginału na sensy swej własnej twórczości. To, co potencjalnie obecne w tekście źródłowym, czyni czymś aktualnie funkcjonującym w języku współczesnej poezji. Na nowo włącza słowa autora Promethidio$n a \mathrm{w}$ obieg współczesnej literatury, zdejmując z nich odium tekstu przeszłości. Tym samym radykalnie zmienia status dziewiętnastowiecznego artysty, czyniąc go partnerem w rozmowie, która toczy się tu i teraz, a więc w jakiejś mierze - poetą XXI-go stulecia...

Podobne wrażenie jest też wzmocnione przez Różewiczowe nawiązania do utrwalonej w kulturze końca XIX wieku legendy Norwida-samotnika. Nie wiemy czy autor Wyjścia znał np. wspomnienia Jana Rosena, który przekazał nam m.in. następujące zdanie: „Norwid, stary już wówczas i bezzębny, równie niechlujny na sobie, jak wokoło siebie [...] i ział napojami wyskokowemi, których, jak wiadomo, używał i nadużywat ${ }^{56}$. Obraz starego mistrza, jaki pojawia się w omawianym utworze, wydaje się wyjątkowo bliski temu, jaki przekazał nam Rosen. Różewicz wyraźnie wydobywa motywy fizycznej starości i brzydoty czy też pijaństwa. Dodajmy jednak, że nie powierza im funkcji semantycznej dominanty, lecz

${ }^{56}$ J. RoSEN, Wspomnienia 1860-1925, Warszawa 1933, s. 66. 
czyni pretekstem do kontrapunktowych obrazów egzystencjalnej tęsknoty, której horyzont przekracza ramy widzialnego świata i kieruje się ku transcendencji. Portret starego poety zyskuje w ten sposób zupełnie inną wymowę. Choć nie brak mu rysów naturalistycznych, to jednak jego przesłanie radykalnie przekracza ramy jakiegokolwiek realizmu. Wiele wskazuje na to, że „,czarna legenda” Norwida została w wierszu Różewicza poddana uniwersalizacji i została wpisana we współczesny mit „starego poety”. Podobnie jak w wielu innych utworach autora Szarej strefy również w analizowanym liryku pojawia się topos samotnego mistrza, którego egzystencja toczy się w samym środku świata ogołoconego z wartości i wypełniona jest tęsknotą za sensem i transcendencją. W twarzy Norwida, jaka pojawia się w omawianym wierszu, dostrzegamy rysy twarzy samego Różewicza. Kreślony przez współczesnego poetę portret starego mistrza ma wiele cech autoportretu. Jeśli styl Różewiczowych nawiązań do tradycji norwidowskiej moglibyśmy nazwać próbą włączenia jej w krwioobieg własnej poezji, to warto podkreślić, że ta transfuzyjna metafora wyraża coś, co nazywamy braterstwem. Współczesny poeta chce, by łączyły go z Norwidem więzy krwi...

Trzeba też na koniec odwiedzić tereny poezji autorów debiutujących po $1989 \mathrm{r}$. Choć wielu z nich wchodziło na parnas pod znakiem postmodernistycznych zabaw z kodami kultury literackiej, a nawiązania do nurtu neoklasycznego rzadko kierowały innych w stronę tradycji norwidowskiej, to jednak warto wskazać co najmniej dwa ciekawe przykłady obecności Norwida w tych nie do końca jeszcze zbadanych terytoriach. Jeden z utworów doczekał się już kilku komentarzy. Wierszowi Jacka Podsiadły ***Atakowany o pólnocy garść uwag poświęcili Mieczysław Inglot ${ }^{57}$ oraz Kamila Byrtek ${ }^{58}$, prezentując radykalnie odmienne sposoby czytania, a więc dochodząc do sprzecznych konkluzji. Inglot zdaje się koncentrować na charakterystyce bohatera tekstu oraz ideowym czy nawet ideologicznym przesłaniu utworu (moim zdaniem niepotrzebnie ${ }^{59}$ ) podczas gdy młoda interpretatorka zasadniczą wartość tekstu Podsiadły upatruje w wyrafinowanej grze literackiej. Przypomnijmy dwie pierwsze strofy tekstu:

57 M. Inglot , W kręgu nawiazań do Norwida, „Polonistyka” 1998, nr 10, s. 652-656.

${ }^{58}$ K. BYrTeK, Poezja Jacka Podsiadly: między kultura wysoka a popkultura, „Kwartalnik Opolski”" 2018, nr 2/3, s. 31-44.

59 Pisałem kiedyś o tym na łamach „Studiów Norwidianów”. Por. W. KudyBA, Norwid w szkole, „Studia Norwidiana” 19: 2002, s. 186-191. 


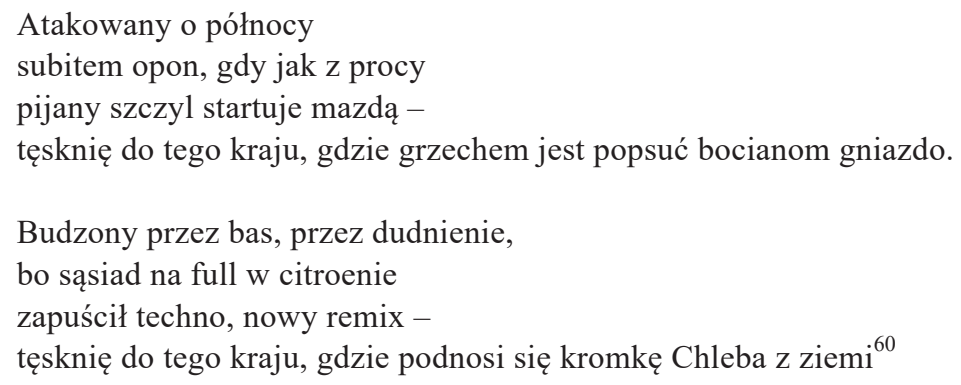

O staraniach poety, umiejętnie żonglującego fragmentami dwóch zdań wyrwanych ze znanego wiersza, Byrtek pisze następująco:

Szczególnie wyraźny kontrast stylów, obrazów oraz rytmów widoczny w przywołanym fragmencie wiersza-poematu ustanawia i jego porządek (24 zwrotki, komponowane według kolejnych liter alfabetu), i jego delimitacyjny refren, będący odbiciem frazy z wiersza Norwida Moja Piosnka II. Skontrastowany rytm i styl powtórzenia (niedokładny cytat z Norwida) tworzy zestawienie dawnego z teraźniejszym (dekontekstualizacja/rekontekstualizacja), pokazuje i wartościuje różne obrazy świata ${ }^{61}$.

Trafnie charakteryzując intertekstualną grę Podsiadły, autorka nie omawia jednak wszystkich konsekwencji jego działań. Można przecież zastanawiać się, jaką funkcję pełni w omawianym wierszu norwidowski archetekst i jakim przemianom semantycznym ulega. Trudno nie zauważyć, że kontrkulturowy poeta, znany ze swych prześmiewczych strategii lirycznych, bawi się frazą antenata niespecjalnie troszcząc się o jej macierzysty kontekst i źródłowe znaczenia. Przeciwnie: warunkiem zabawy staje się tu pozbawienie norwidowskiej frazy jakichkolwiek związków z pierwotnym środowiskiem i rzucenie jej w radykalnie obcy dla niej kontekst. Wykorzystując wysokie nacechowanie stylistyczne kanonicznej frazy, autor zręcznie zestawia ją nie tylko ze współczesnym idiomem kolokwialnym, ale i bylejakością naszej rzeczywistości. Buduje w ten sposób pomiędzy obydwoma biegunami komiczne napięcie, które niczego nie odbiera obrazom współczesności, w istotny sposób zubaża jednak wymowę norwidowskiej frazy: odbiera jej nie tylko powagę, ale i znaczenie. Słowa Norwida wydają się być w omawianym wierszu jedynie żetonami w literackiej, ludycznej grze. Niczym więcej...

${ }^{60}$ Tekst dostępny jest w zasobach internetowych, por. www.wolnelektury.pl/media/book/pdf/ podsiadlo-atakowany-o-polnocy.pdf (dostęp: 27.12.2020).

${ }^{61}$ K. ByrteK, s. 34. 
Wszystko to nie oznacza jednak, że autentyczne spotkanie współczesnych poetów z Norwidem nie jest dziś możliwe. W środowisku autorów skupionych wokół spockiego „Toposu” od wielu lat toczy się przecież owocna dyskusja z tradycją romantyczną. Niech wystarczy tu jeden przykład. W 2013 r. w „Bibliotece Toposu" ukazał się zbiór wierszy Przemysława Dakowicza Teoria wiersza polskiego. Tom był szeroko komentowany, a jego autor doczekał się ważnych nagród literackich. Odnajdujemy w tej książce m.in. następujący utwór:

Niechybnie!

Dlatego niechętnie chodziłem do Cyprjana

Norwida mieszkanie jego wspomina

Jan Rosen przedstawiało obraz

Nędzy i Rozpaczy Brud i Złe

Powietrze panowały tam

niepodzielnie

sam Norwid stary już wówczas

i Bezzębny równie Niechlujny

na sobie jak wokoło siebie Gwizdał

przeraźliwie mówiąc

I Ział

Napojami Wyskokowemi których

jak wiadomo używał i nadużywał

mówił chętnie i obficie

ale mglisto

Pantaleon Szyndler

teorie mistyczne Norwida przekształcił

w fanatyczną wiarę i

niestety

pod wpływem Norwida

zaczął Pić umarł w zakładzie

dla obłąkanych w Częstochowie

[w Częstochowie!]

po licznych atakach 
Delirium Tremens
nie odbierałem też
w obcowaniu z nim
[Norwidem]
wrażenia wielkości
ducha
ten brak dbałości o
zewnętrzny wygląd
ta oczywista Niechlujność
(na nim i wokoło niego)
przyczyniać się musiały
niechybnie
do
niepowodzeń
jego
Warszawa 1933 - Łódź $2012^{62}$

Jeśli pamiętamy cytowany przy okazji interpretacji tekstu Różewicza fragment książki Jana Rosena, to łatwo dostrzeżemy, że Dakowicz po prostu rozpisuje na wersy wspomnienia malarza (uzupełniając je wtrąceniami w kwadratowych nawiasach). Swój gest powtórzenia wyjawia zresztą w paratekście, podając zarówno miejsce i datę wydania memuaru, jak i własne miejsce zamieszkania oraz rok pracy nad utworem. Nie oznacza to jednak, że rezygnuje z możliwości znaczeniowego modelowania wynurzeń Rosena. Przeciwnie: za pomocą kilku prostych zabiegów radykalnie zmienia ich wymowę. Pierwszym z nich jest oczywiście delimitacja. Samo rozczłonkowanie wspomnieniowej narracji na wersy otworzyło możliwość rozkładania semantycznych akcentów w zupełnie innych miejscach niż było to intencją jej autora. Natomiast umiejętne zastosowanie przerzutni pozbawiło dyskurs znaczeniowej oczywistości, nakazało lekturę uważną, podejrzliwą, skierowaną na głębokie warstwy tekstu. Tę samą funkcję zdają się pełnić wielkie litery. W memuarze są one jedynie sygnałem początku zdania, podczas gdy u Dakowicza stają się swoistym szyfrem podważającym powierzchniowe znaczenie poszczególnych fraz i kierującym w stronę tego, co ukryte.

Na czym więc polega to osobliwe wrażenie, że znaczenia tekstu przepisanego przez Dakowicza są gdzie indziej niż w nim samym? Wydaje się, że odpowiedzią

${ }^{62}$ P. Dakowicz, Teoria wiersza polskiego, Sopot 2019, s. 37-38. 
na tak postawione pytanie jest ironia. Przenika ona nie tylko całą Teorię wiersza polskiego, ale jest też niezwykle ważnym elementem poetyki Dakowicza. Choć rzecz wymaga zapewne wnikliwych badań, zaryzykowałbym tezę, że ma ona wiele wspólnego z ironią romantyczną - jest poetycką odpowiedzią na zło historii, zapisem niezgody na świat, który nie jest taki, jaki powinien być. Ironiczną wymowę tekstu sugeruje przede wszystkim jego formuła tytułowa - nacechowana właśnie gorzką ironią. Tytułowe "niechybnie” zdaje się mieścić całą gorycz zgody na nędzny los i buntu przeciw - czemu właściwie? Przeciw historii? Przeciw społeczeństwu? Celem współczesnego poety nie jest odbrązowienie legendy Norwida i kompromitacja publicznego wizerunku „czwartego wieszcza” ale sarkastyczny sprzeciw wobec sytuacji, jaką los zgotował wybitnemu pisarzowi. Dodajmy przy tym, że chodzi w tomie nie tyle o los indywidualny, ile raczej o los zbiorowy, polski - dyktowany przez wydarzenia dziejowe. Podobnie jak u Różewicza, również tu Norwid staje się kimś spośród nas, naszym współczesnym - dziedzicząc los, który w jakiejś mierze jest również naszym udziałem. Także tu pod historyczną maską odkrywamy twarz współczesnego autora i jego moralną wrażliwość. Czy tak jest w całej twórczości współczesnego poety? Wiele wskazuje na to, że tak. Ślady głębokiego zanurzenia w tradycję norwidowską odnajdujemy w rozmaitych warstwach Dakowiczowej poezji - w zabiegach kompozycyjnych, w predylekcji poety do cykliczności, w jego myśleniu o kulturze i o społeczności, w specyficznej nucie wrażliwości moralnej, a przede wszystkim właśnie w takim odcieniu ironii, który bardzo przypomina ironię Norwidowską. Czas przyjrzeć się dokładnie spotkaniu Dakowicza z autorem Assunty. Pokaźny już dorobek literacki łódzkiego poety i norwidologa domaga się gruntowniejszych analiz komparatystycznych. Żałuję, że zabrakło dla nich miejsca w niniejszym szkicu.

Jak to już zostało powiedziane, chodziło mi bowiem o działania propedeutyczne, wskazujące drogę ku przyszłej monografii. Przed jej autorami rysuje się niełatwe zadanie. Wydaje się, że tradycja norwidowska jest nie tylko uobecniana w tekstach wielu współczesnych poetów, ale i bywa przywoływana przez badaczy na tyle często, że trudno dziś znaleźć wybitnego polskiego pisarza XX wieku, którego postać nigdy nie była portretowana z Norwidem w tle. Ludowość Tadeusza Nowaka ${ }^{63}$, „ciemność” Grochowiaka ${ }^{64}$, muzyczność Czechowicza ${ }^{65}$ - by po-

${ }^{63}$ Por. J.Z. Brudnicki, Tadeusz Nowak, Warszawa 1978, s. 54.

${ }^{64}$ Por. J. KwiatKowski, Ciemne wiersze Grochowiaka, w: tegoż, Klucze do wyobraźni. Szkice o poetach współczesnych, wyd. II Kraków 1973, s. 123-131.

${ }^{65}$ Por. J. Fert, Norwid i Czechowicz: poszukiwanie „,czystego tonu”, „Ethos” 2006, nr 1/2, s. 231-247. 
przestać na najbardziej wyraźnych przykładach wspomnianej tendencji - zyskują w ten sposób szlachetny rodowód, a więc i odpowiednią historycznoliteracką rangę, nie oznacza to jednak, że w ten sposób został opisany ich rzeczywisty dialog wymienionych pisarzy z autorem Quiama. Kiedy indziej wybrany okruch Norwidowej spuścizny pojawia się jako poręczny kontekst w lekturze pojedynczych utworów - pozwalający poszerzyć horyzont interpretacji o elementy analiz intertekstualnych ${ }^{66}$. Bywa, że w takim właśnie celu zestawia się motywy pojawiające się u Norwida i wybranego współczesnego poety ${ }^{67}$. Podobne działania mogą oczywiście zachęcać do prób opisu tego, co chciałoby się nazwać dialogiem, ale nie mogą takiego opisu zastąpić... Ów wymiar podmiotowy, wymiar osobowego spotkania wydaje mi się w badaniach komparatystycznych najciekawszy. Może synteza poświęcona obecności tradycji norwidowskiej w poezji współczesnej będzie musiała kiedyś przybrać kształt panoramy indywidualnych spotkań poszczególnych pisarzy z autorem Assunty?

\section{BIBLIOGRAFIA}

BarańcZaK S., Norwid: obecność nieobecnego, w: tegoż, Tablice z Macondo. Osiemnaście prób wyttumaczenia po co i dlaczego się pisze, Kraków 2018, s. 119-134.

BŁoński J., Norwid wśród prawnuków, „Twórczość” 1967, z. 5, s. 67-94.

DAKowicz P., „Lecz ty spomnisz wnuku...” Recepcja Norwida w latach 1939-1956. Rzecz o ludziach, książkach i historii, Warszawa 2011.

IngLOT M., Mieczystawa Jastruna lwowskie spotkania z Norwidem. (1939-1941), „Studia Norwidiana" 7: 1989, s. 119-126.

JARZYNA A., „Pójście za Norwidem”(w polskiej poezji współczesnej), Lublin 2013.

Lisowski K., Z Tadeuszem Różewiczem nie tylko o Norwidzie, „Odra” nr 4/5, 2000, s. 7-16.

MikolajCzak M., Czy piękno ocala? O jednym z watków dialogu Herbert - Norwid, w: taż, Światy z marzenia. Echa romantyczne w poezji Zbigniewa Herberta, Kraków 2011, s. 93-110.

NiEUKERKEN A. van, Ironiczny konceptyzm. Nowoczesna polska poezja metafizyczna w kontekście anglosaskiego modernizmu, Kraków 1998.

NieUKerken A. van, Perspektywiczność sacrum - szkice o Norwidowskim romantyzmie, Warszawa 2007.

${ }^{66}$ Por. W. Kudyba, Świętość stowa w wierszu „Do Ryszarda Krynickiego - list”, w: „, Nie powinien przysyłać Syna”, red. J. Ruszar, Kraków 2018, s. 185-196.

${ }^{67}$ Por. np. M. Inglot, „, A Dorio ad Phrygium” Cypriana Norwida i ,, apollińskie” wiersze Zbigniewa Herberta. Paralele, w: tegoż, Wyobraźnia poetycka Norwida, Warszawa 1988, s. 49-61; J. FERT, Norwid - Herbert. Epizod z guzikami, ,Roczniki Humanistyczne KUL” 1999, z. 1, s. $97-118$. 
Rygielska M., Przyboś czyta Norwida, Katowice 2012.

Sawicka K., Norwid Tadeusza Różewicza-deklaracje, w: Polska literatura wspótczesna wobec romantyzmu, red. M. Łukaszuk, D. Seweryn, Lublin 2007, s. 129-141.

Sawicka K., Różewicz-Norwid, w: Dialogi romantyczne, red. E. Kasperski, T. Mackiewicz, Warszawa 2008, s. 391-409.

Skrendo A., Stanisław Barańczak: widma poezji, „Teksty Drugie” 2014, nr 2, s. 284-306.

WóscıK L., Wpływ Norwida na poezję Kwadrygi. (Fragmenty), „Przegląd Humanistyczny” $1967 \mathrm{nr} \mathrm{4,} \mathrm{s.} \mathrm{59-84.}$

\title{
NORWID W POEZJI WSPÓŁCZESNEJ. FORMY OBECNOŚCI
}

\begin{abstract}
Streszczenie
Artykuł odpowiada na pytanie o to, jaki kształt mają odniesienia do Norwida w tekstach poetów reprezentatywnych dla naszej współczesności. Przedmiotem opisu sąfunkcje takich intertekstualnych nawiązań - najpierw na terenie świadomości zbiorowej. Okazuje się, że w dwudziestoleciu międzywojennym i w czasie wojny sięgano do dzieł romantycznego mistrza na wszystkich etapach budowania własnej literackiej tożsamości. Czytano nie tyle teksty Norwida, ile raczej samych siebie w obliczu jego dzieł. Natomiast po 1956 roku obecność Norwida we wspólnotach pisarzy wyrasta raczej z potrzeb historyków literatury niż z rzeczywistych odniesień międzytekstowych. Ta tendencja obecna jest także na terenie badań twórczości pojedynczych autorów. Zdarza się - zwłaszcza wtedy, gdy mówimy o implicytnych śladach obecności Norwida w poezji współczesnej - że płaszczyzna relacji pomiędzy autorami nie jest przez interpretatorów przywoływana. Bywa, że dialog jako kategoria badawcza znika z pola ich obserwacji, a korpus dzieł Norwida jest traktowany jedynie kontekstowo - staje się pewnego rodzaju lustrem, które służy pełniejszej prezentacji jakieś właściwości twórczości wybranego autora lub motywu, który w niej występuje. Najważniejszych formy funkcjonowania autora Quidama w naszej współczesności to te, które osiągają wymiar spotkania (udanego lub nieudanego). Tak dzieje się w przypadku fascynacji poezją Norwida obecnej m.in. w tekstach Mieczysława Jastruna, Juliana Przybosia, czy też Tadeusza Różewicza.
\end{abstract}

Słowa kluczowe: Norwid, intertekstualność, poezja współczesna 


\title{
NORWID IN CONTEMPORARY POETRY. FORMS OF PRESENCE
}

\begin{abstract}
The article attempts to establish the character of references to Norwid in texts by poets representative of Polish modernity, accounting for functions of intertextual allusions, initially in the area of collective consciousness. As it turns out, during the interwar period and the Second World War works by the Romantic master were referenced at all stages of developing a distinct literary identity. Poets would not just read Norwid's texts, but in fact regard themselves in the mirror of his works. However, after 1956 Norwid's presence in literary life was rooted in the needs of literary scholars rather than in actual intertextual references. This tendency also manifests in studies of works by individual authors. It does happen - especially when we speak of implicit traces of Norwid in contemporary poetry - that the plane of relations between authors is not addressed by interpreters. Sometimes, dialogue as a research category disappears from their view, while the body of Norwid's works is treated merely as a context, becoming a kind of mirror meant to display more fully a certain theme or characteristic of somebody's writing. However, the most important forms of Norwid's functioning in contemporary times are ones that facilitate meetings(successfulor not), as demonstrated by the fascination with Norwid's poetry recognizable in texts by authors such as Mieczysław Jastrun, Julian Przyboś and Tadeusz Różewicz.
\end{abstract}

Translated by Grzegorz Czemiel

Key words: Norwid, intertextuality, contemporary poetry

WojCIECH KUdYBA - prof. dr hab., kierownik Katedry Literatury XX wieku Uniwersytetu Kardynała Stefana Wyszyńskiego w Warszawie. Autor książki „,Aby mowę chrześcijańska odtworzyć na nowo... Norwida mówienie o Bogu (Lublin 2000) oraz kilku monografii o poezji współczesnej Rana która przyzywa Boga. O twórczości poetyckiej Janusza St. Pasierba, (Lublin 2007); Wiersze wobec Innego, (Sopot 2012); Generacja źle obecna, (Sopot 2014) Próba bólu. O wierszach Joanny Pollakówny (Warszawa 2016) Pamięć i godność. O poezji Jana Polkowskiego (Warszawa 2019) - a także artykułów naukowych publikowanych m.in. w „Studia Norwidiana”, „Pamiętniku Literackim”, „Tekstach Drugich” „Ethosie”, „Rocznikach Humanistycznych KUL” oraz „Ruchu Literackim”. 